\title{
The feasibility of national parks in South Africa endorsing a community development agenda: The case of Mokala National Park and two neighbouring rural communities
}

\begin{tabular}{|c|c|}
\hline \multicolumn{2}{|c|}{$\begin{array}{l}\text { Authors: } \\
\text { Hendri Coetzee }{ }^{1} \text { @ } \\
\text { Werner Nell }{ }^{2}\end{array}$} \\
\hline \multicolumn{2}{|c|}{$\begin{array}{l}\text { Affiliations: } \\
{ }^{1} \text { Institutional Sustainability } \\
\text { and Community Impact Office } \\
\text { and Unit for Environmental } \\
\text { Sciences and Management, } \\
\text { North-West University, } \\
\text { South Africa }\end{array}$} \\
\hline \multicolumn{2}{|c|}{$\begin{array}{l}{ }^{2} \text { Optentia Research } \\
\text { Programme, North-West } \\
\text { University, South Africa }\end{array}$} \\
\hline \multicolumn{2}{|c|}{$\begin{array}{l}\text { Corresponding author: } \\
\text { Hendri Coetzee, } \\
\text { hendri.coetzee@nwu.ac.za }\end{array}$} \\
\hline \multicolumn{2}{|c|}{$\begin{array}{l}\text { Dates: } \\
\text { Received: } 04 \text { Apr. } 2017 \\
\text { Accepted: } 19 \text { Sept. } 2018 \\
\text { Published: } 28 \text { Feb. } 2019\end{array}$} \\
\hline \multicolumn{2}{|c|}{$\begin{array}{l}\text { How to cite this article: } \\
\text { Coetzee, H. \& Nell, W., 2019, } \\
\text { 'The feasibility of national } \\
\text { parks in South Africa } \\
\text { endorsing a community } \\
\text { development agenda: The } \\
\text { case of Mokala National } \\
\text { Park and two neighbouring } \\
\text { rural communities', Koedoe } \\
61(1), \text { a1470. https://doi.org/ } \\
\text { 10.4102/koedoe.v61i1.1470 }\end{array}$} \\
\hline \multicolumn{2}{|c|}{$\begin{array}{l}\text { Copyright: } \\
\text { (C) 2019. The Authors. } \\
\text { Licensee: AOSIS. This } \\
\text { is licensed under the } \\
\text { Creative Commons } \\
\text { Attribution License. }\end{array}$} \\
\hline \multicolumn{2}{|l|}{ Read onlin } \\
\hline 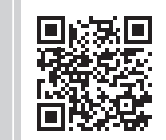 & $\begin{array}{l}\text { Scan this QR } \\
\text { code with your } \\
\text { smart phone or } \\
\text { mobile device } \\
\text { to read online. }\end{array}$ \\
\hline
\end{tabular}

This article explores the feasibility of South African National Parks (SANParks) endorsing a community development agenda, using Mokala National Park (MNP) and two neighbouring rural communities as case study. A three-phase sequential exploratory, mixed-methods approach was followed: an initial exploratory qualitative phase aimed at identifying the development needs of the two communities; a quantitative phase aimed at verifying and quantifying the identified needs; and a final qualitative phase (with a minor quantitative component) to determine what parks can reasonably achieve in terms of community development based on their available resources, capacity and expertise. Qualitative data were collected via semi-structured interviews (Phase 1: $n=22$; Phase 3: $n=6$ ), which were thematically analysed. Quantitative data were collected via a structured questionnaire (Phase 2: $n=484$; Phase 3: $n=6$ ) and analysed using SPSS 23. Findings revealed that the communities' most significant needs centred on employment opportunities; improved healthcare, service delivery and waste management; and education. Community members also expressed the need for improved community policing, safety and security; social services; agricultural support and training; general skills development and training; local leadership; recreational facilities; local economic development and conservation initiatives. Results from the third phase of the study suggest that parks such as MNP can realistically only address some of the identified community needs significantly; primarily job creation (via temporary employment), skills development, local economic development, support of local conservation (especially via environmental education) and, to a lesser extent, agricultural support and training and permanent job creation.

Conservation implications: The findings could be of practical use to SANParks to steer its community development initiatives towards attaining a more optimal balance between actual community needs and what the organisation can realistically offer, thus rendering SANParks' efforts more efficient and effective in supporting the establishment of equitable and sustainable rural communities.

\section{Introduction}

National parks can potentially play an important role in rural community development. This sentiment is shared by researchers from all over the world, including Africa (Newmark \& Hough 2000; Petursson \& Vedeld 2017), the Americas (Machlis \& Field 2000; Nelson \& Serafin 2013), Europe (Barrow 2015; Lundmark, Fredman \& Sandell 2010), Asia (Kusters et al. 2006; Tisdell 1999) and Australia (Stolton \& Dunley 2015). This notion is also supported by a recent report by the Global Environmental Fund's Scientific and Technical Advisory Panel (Pullin 2014), which outlines the impacts that protected areas (e.g. national parks) can have on rural communities, especially with regard to environmental capital (e.g. resource use and access to land), economic and social capital, health and inequality.

The idea of national parks adopting a developmental agenda stems from a paradigm shift away from traditional forms of conservation (preservation) to more contemporary forms that encompass both conservation and development objectives (Anthony 2007). This led to what is widely known today as community-based conservation (CBC) (Berkes 2007). The underlying principle of this combined approach is that poor rural communities should benefit directly from conservation (Cock \& Fig 2000). 
Several variations of the approach developed over the years, including (1) that communities should develop their own traditional or cultural land into conservation areas (IUCN 2010; Stevens 2014); (2) that communities should support protected areas and, in return, that they ought to benefit from job creation, skills development and other types of development in their communities (Bennet 2014; Pelser, Redelinghuis \& Velelo 2013); (3) that communities should be allowed to harvest grass, wood, medicinal plants and other natural resources from parks (Cock \& Fig 2000; SANParks 2016); and (4) the use of 'trade-offs', where certain areas (and the biodiversity contained therein) are protected whilst other parts of the park are made available for development (Rights \& Resource Initiative 2015). Mokala National Park (MNP), which serves as a case study in this article, is a good example of a trade-off approach being applied within a South African context, as it is basically a 'trade-off park'1 in the place of the former Vaalbos National Park that was handed back to a local community as part of a land restitution case (SANParks 2017).

Elements of these variations to $\mathrm{CBC}$ can also be found in the latest version of SANParks' 5-year strategic management plan (2015/2016-2019/2020) and, more specifically, in its strategic outcome-orientated Goal 3, in terms of which SANParks' goal is (SANParks 2016):

$[t]$ o foster an efficient, effective and development oriented public service and an empowered, fair and inclusive citizenship that will enable the creation of decent employment through inclusive economic growth, vibrant, equitable and sustainable rural communities. (p. 28)

As outlined in the document, this plan is underpinned by the current national government's 'five key pillars', which include job creation, rural development, education and health, as well as a reduction in the levels of crime in society.

SANParks adopted a vision 'Connecting to Society' (SANParks 2012), created a Social Ecology Unit (Swemmer \& Taljaard 2011), expanded the scope of its people and conservation programme and added several programmes aimed at promoting access and benefit-sharing, socioeconomic development and improved living conditions for local communities adjacent to national parks. This encompasses the implementation of national government's expanded public works programmes (EPWP) (e.g. working for water, land, wetlands, the coast, fire, etc.), value-adding industries, wildlife economy, the development of small, medium and micro-sized enterprises (SMMEs) and a number of social investment programmes at almost all of the national parks (SANParks 2012).

It is not difficult to justify national parks in South Africa endorsing a development agenda. From a conservation perspective, an interdependence between biodiversity and sustainable rural development is needed (Faasen 2006), and that it can be used for reasons other than
and in its place another park is proclaimed. much has been written about the threat of unsustainable land-use practices as well as the impact that resource-poor, hunger-stricken rural communities may have on biodiversity and wildlife (Vira \& Kontoleon 2010). From a development perspective, this approach also makes sense as parks are scattered throughout South Africa, often in deep rural areas where government cannot always address all the needs in these communities, which are often resource-poor and desperate for help and support from others (Flora, Flora \& Gasteyer 2015; Mohan 2009).

The benefits of a CBC approach, as well as the costs thereof and the challenges it poses, have been widely reported (Botha, Witkofski \& Cock 2007; Murphee \& Hulme 2001; Western, Wright \& Strum 2013). Most authors seem to concur that CBC, at best, has only achieved mixed results (Berkes 2004; Conley \& Moote 2003; Mansuri \& Rao 2004). Many reasons for this have been given (Cox, Arnold \& VillamayorTomas 2010), which centre mainly around the fact that community development objectives and conservation objectives are often incompatible and that the benefits derived from community-conservation partnerships are often one-sided, primarily benefitting a conservation rather than a community development agenda (Emerton 2001).

One possible strategy to investigate and address these concerns further is to assess the actual needs of communities adjacent to national parks empirically (Wells \& McShane 2004) in light of existing literature as well as on the basis of a qualitative exploration pertaining to national parks' current and proposed community development strategies as well as their pool of available resources, skills et cetera. This would enable the feasibility of various development initiatives to be assessed in the light of empirical evidence about what specific communities identify as their particular needs, which, in turn, will allow for distinctions to be made in terms of the viability of specific strategies as outlined in existing SANParks documentation. Furthermore, this approach could potentially address the one-sidedness of the relationship between parks and communities by ensuring that the development side of CBC initiatives articulates self-identified community needs.

Although SANParks has already adopted a developmental approach, given limitations such as restrictions on specific development-related skills and expertise (Berkes 2007; Biggs et al. 2014; Pelser et al. 2013) that fall outside the typical skills required for park personnel, capacity and resources, the extent to which national parks can play a substantive role in community development needs to be investigated. To address these questions, a sequential exploratory, mixedmethods study was conducted in two rural communities (Ritchie and Ratanang) near MNP in order to explore what the typical developmental needs within communities situated near a national park are. This was followed by an additional qualitative study (with a minor quantitative component) aimed at exploring MNP's available capacity, skills and expertise and current $\mathrm{CBC}$ initiatives. Following this, the identified community needs were evaluated in 
the light of a theoretical and empirical investigation of SANParks' CBC initiatives as well as the organisation's capacity, resources and expertise with the intention to assess the feasibility of such needs being addressed by parks such as MNP.

\section{Research method and design \\ Study area}

Mokala National Park is situated in a semi-arid part of central South Africa near Kimberley in the Northern Cape Province (Figure 1). Ritchie, with a total estimated population size of 3504 (Stats-SA 2011), is situated on the Northern Cape side of the border near Modderrivier, an area that falls within the Frances Baard District Municipality and Sol Plaatjies Local Municipality, whilst Ratanang, with a total estimated population size of 4213 (Stats-SA 2011), borders Jacobsdal, which is located on the Free State side of the border and falls within the Xhariep District and Letsemeng Local Municipality (see Figure 1). The largest portion of the population in both areas classify themselves as mixed race and speak mostly Afrikaans (Stats-SA 2011). The two communities were selected as they are the communities closest to Mokala.

\section{Design}

A mixed-methods approach, based on a pragmatic paradigm (Creswell \& Plano Clark 2007; Johnson, Onwuegbuze \& Turner 2007), was followed in the present study, which was

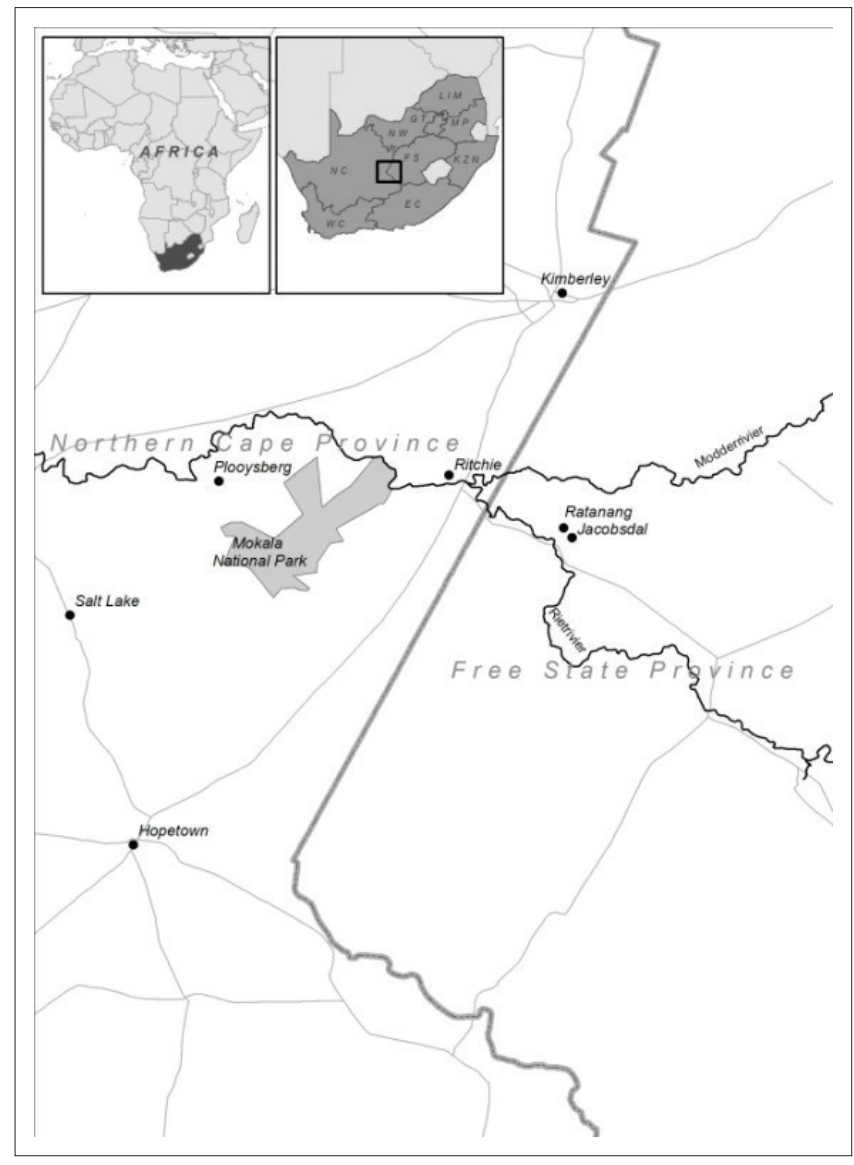

FIGURE 1: Map of the study area. executed in three sequential phases: an initial exploratory qualitative phase aimed at identifying the development needs in the two communities; a quantitative phase, where a structured survey was developed and administered to verify and quantify the needs that were identified during the first phase; and a final qualitative phase (with a minor quantitative component) to determine what parks can reasonably achieve based on their available resources, capacity and expertise. This type of approach is widely accepted as one of the most useful approaches to research, because it provides multiple perspectives on a given topic (Creswell 2003) and also affords researchers the opportunity to further explore and explain quantitative results, which, according to Tashakkori and Teddlie (2003), will add richness, depth and greater credibility to any study.

\section{Participants}

During the course of the study, three different groups of participants were recruited. A similar procedure was followed during the first $(n=22)$ and third $(n=6)$ qualitative phases of the study, where participants were purposively selected (Creswell 2013) based on their knowledge and experience relevant to the research aims. This approach was supplemented with a snowball sampling strategy, where initially selected participants were requested to refer the researchers to other potential participants who met the sampling criteria (Creswell 2013). The purposive sampling criteria that were set for the first phase required that participants had to be active participants in, or residents of, one of the two communities and had to occupy a central or leadership role in the community. The community leaders were identified via snowball sampling. The initial sample was comprised of two staff members from MNP, two staff members from SANParks, two ward councillors, a school principal, two local policemen, two nurses heading up community clinics and the two social workers appointed to work in these communities. An additional number of nine community members representing different stakeholder groups (e.g. youth, elderly, women, etc.) were recruited by means of typical instance sampling (Tracy 2013).

Four hundred and eighty-four participants participated in the second, quantitative phase of the study. Of these, 300 resided in Ritchie (the larger of the two communities) and 184 in Ratanang. A systematic sampling frame (Creswell 2003) was used in order to ensure that all areas of each community were surveyed. Using this approach, every $n$th household (determined by the total number of participants required for the study in relation to the number of households in each community) was surveyed in each community. The mean age of the participants was 35.97 years $(\mathrm{SD}=14.18)$, with ages ranging from 18 to 86 years. Other relevant demographic information pertaining to the sample is presented in Table 1.

During the third phase, six participants were purposively selected (Tracy 2013) on the basis of having first-hand experience in what MNP or SANParks can realistically 
TABLE 1: Characteristics of the participants who took part in the quantitative phase of the study $(n=483)$.

\begin{tabular}{lcc}
\hline Characteristic & Frequency & $\%$ \\
\hline Gender & & \\
Male & 223 & 46.5 \\
Female & 257 & 53.5 \\
Race & & \\
White & 7 & 1.5 \\
Black & 154 & 32.0 \\
Mixed race & 321 & 66.6 \\
Asian & 0 & 0.0 \\
Work status & & \\
Student & 21 & 4.4 \\
Unemployed & 255 & 53.3 \\
Entrepreneur & 11 & 2.3 \\
Retired & 27 & 5.6 \\
Part-time employment & 72 & 15.1 \\
Full-time employment & 92 & 19.2 \\
\hline
\end{tabular}

achieve in the development space. The participants consisted of a very experienced park manager who managed several national parks in South Africa, a People and Conservation officer who had also worked in multiple parks, the head of the park interface programme, a section ranger and two scientists from SANParks' regional office in Kimberley who worked in all the parks in the arid node.

\section{Procedure and ethics}

The first phase of the study took place in early 2016 after ethics clearance was obtained from the North-West University's Human Research Ethics Committee (NWU-00342-15-S1). Once entry into the community had been negotiated, semi-structured interviews were conducted with key participants by the authors and, based on the findings, a structured questionnaire was developed that was subsequently administered to residents of the two communities during the second phase of the study, which took place 1 year later. Eighteen fieldworkers (8 from Ritchie and 10 from Ratanang) were recruited from the respective communities and subsequently trained to administer the survey. Fieldworkers were compensated financially for their services. Informed consent was obtained from all participants. Data were collected over a period of 1 week. Privacy and confidentiality (which are also covered in the informed consent form) were protected by conducting the interviews in a place where the participants felt comfortable (e.g. their homestead) and by making sure that no one other than the researcher had access to the participant's identifiable characteristics linked to specific results. Furthermore, fieldworkers were required to sign confidentiality agreements. Completed questionnaires were inspected on receipt to ensure completeness and correctness and were subsequently taken to the North-West University's Statistical Consultation Services for data capturing and analysis.

During the third qualitative phase of the study, an interview guide and a structured questionnaire were developed based on the results of phases 1 and 2 and were subsequently utilised to gather data from six purposively selected senior members of MNP and SANParks.
In total, the project involved 4 full weeks of fieldwork, which spanned a period of 3 years.

\section{Data gathering methods}

During the first (qualitative) phase of the study, data were gathered by means of semi-structured interviews with purposively selected members of the two communities. An interview guide (Tracy 2013) was used to facilitate the interviews. In particular, all participants were asked what they believed to be the most pressing needs in their respective communities.

During the second (quantitative) phase of the study, a structured survey was developed on the basis of the themes that were identified from the first set of semi-structured interviews as outlined previously (see Table 2 for the complete list of items). This strategy was followed in order to ensure that the scale was contextually sensitive and that the items on the scale tapped into actual community needs, as well as to enable the qualitatively identified needs to be empirically quantified and verified. Specifically, participants were requested to rate each of the listed needs on a fivepoint Likert scale ranging from 1 ('no need') to 5 ('a very big need'). In addition, the survey was structured to gather biographical data pertaining to participants' gender, age, race and employment status.

During the third qualitative phase of the study, data were gathered by means of an interview schedule and structured questionnaire, which were developed on the basis of the findings that emerged from phases 1 and 2 of the study. Participants were requested to rate a list of community needs on a five-point Likert scale (ranging from $1=$ 'not at all' to $5=$ 'to a great extent') based on their professional view of the extent to which parks like MNP could potentially address each specific need. Participants were then requested to qualitatively elaborate on the reason for their ratings via semi-structured interviews or questionnaires.

\section{Data analysis}

Qualitative data derived from phases 1 and 3 of the study were analysed by means of thematic content analysis (Creswell 2003; Tracy 2013). The transcribed data were first read multiple times to ensure immersion in the data, after which data were inductively coded by assigning a brief descriptive label to each segment of text. Based on conceptual similarities, codes were grouped together into categories and overarching themes. These themes formed the basis for the development of the structured survey, which was used to gather data during the second round of the study.

Quantitative data were statistically analysed using SPSS 23 (Field 2005). Descriptive statistics (means and measures of central tendency) were calculated for all items. 
TABLE 2: Community needs.

\section{Need}

\section{Community conditions}

Description

Need for employment

The need for local conservation initiatives

\section{Business-related services}

Local economic development

Government-related services

Public education

The need that was most frequently expressed by all participants was for employment, as unemployment was regarded as one of the most pressing of all problems in these communities.

A need to conserve biodiversity was reported, which was deemed by some participants to include the protection of birds, mammals, reptiles and other animals, as well as plants and water sources (the Riet River) in the community.

This need was illustrated by accounts that large numbers of birds and small mammals such as hares were hunted by especially the children in their communities, and that reptiles like snakes were killed indiscriminately.

This comprises the need for the establishment of small businesses and/or the creation of business opportunities, as well as the establishment of shops where life necessities and other items can be purchased (especially in Ritchie and, to a lesser extent, in Jacobsdal).

The participants identified three needs related to education. Firstly, they identified the need for an improvement in the quality of education (at primary and secondary level); secondly, they identified the need for more schools in the area; and thirdly, they identified the need for access more schools in the area; and thirdly, they

Skills development and training

Healthcare services

Social services

Improved infrastructure

Safety, security and community policing

Recreational facilities, activities and opportunities

Non-profit-related services

Improved local leadership leadership structures are reported to have many shortcomings, and
moreover a lot of infighting and conflict seem to occur among leaders.
The need for vocational training and for equipping community members with some sort of practical skill that can help them find jobs was highly emphasised. The absence of skills and formal training was perceived as the main reason why unemployment is so rife in these communities. In contrast, other participants stated that there were already many skilled workers, such as carpenters and those skilled in craft work, in the community. However, according to residents, the challenge is that they are far from major tourist routes and it is therefore not feasible to continue this line of work. A need therefore exists for skilled residents to have opportunities to ply their trades and/or sell their wares.

According to the participants, there are no resident general practitioners (doctors, dentists, etc.) or hospitals in their immediate area. Community members therefore have to rely on the medical services offered by their local clinics. However, many participants are not satisfied with the number of healthcare workers that are available at local clinics.

This comprises the need for improved social services and, in particular, the need for more social workers and the types of services they offer. This was confirmed by two interviewed social workers who both said that they did not have the capacity to handle all the cases that land on their table in a speedy and effective manner. They also confirmed that there is a dire need for increased social services in these communities.

This comprises participants' needs for roads, water, electricity and sanitation. Many roads in the community are not tarred and in a very poo condition. Furthermore, water supply is reportedly often unreliable, an many areas still do not have electricity and proper sanitation (though several recent improvements and new developments in this regard have been reported).

Many participants were of the opinion that an urgent need exists for something to be done about the large amount of waste, such as plastic are reported to be a source of disease and death among livestock as well as illness among children in the communities.

Many participants expressed a pressing need in relation to safety and that they rarely go out of their homes at night for this reason and that they are often victims of burglaries and theft.

Although there are police stations in Ritchie and in Jacobsdal (which serves the Ratanang community), most community members were of the opinion that there is a need to improve the services that are typically rendered by the police. This includes visible policing and the investigation of cases. In an interview with one of the local police officers, it was confirmed that they do indeed experience serious capacity problems.

Currently, very limited recreational facilities and opportunities exist in these communities, apart from a sports and recreation facility that is now under construction in Ratanang, basic sports facilities at the primary school in Ritchie and an informal soccer pitch, where community members normally gather over weekends. As a result, young children and teenagers are reported to often roam the streets and engage in mischief and petty crimes like burglaries. Most participants felt that there is a deeper dimension to this need as it would provide youth with recreational outlets that would serve as alternative to unhealthy forms of rivalry, violence and gangsterism that are currently rife in these communities. bags, bottles and paper that are present throughout the communities and security and reported that they often felt unsafe - with many reporting

\section{Illustrative excerpt from interviews}

'In our community many people don't have jobs. We can do nothing there are no opportunities.' (Participant 5, male, ward councillor)

'This is a beautiful area. I love nature. The problem here is that most people don't care about nature. As children we used to go to the river [Riet River]. There used to be large trees there where we played and swam in the river. All the trees are now gone and there are papers everywhere.' (Participant 8 , male, police officer) 'Here people don't care. If they see a snake, they just kill it. Even if it is not poisonous [venomous].' (Participant 6, male, ward councillor)

'It is a big challenge for us. You can buy almost nothing here [in Ritchie] We have to travel to Kimberley. It is very far ...' (Participant 10, female, clinic nurse)

'Our children suffer ... education is not good here in our community [Ritchie].' (Participant 5, male, ward councillor)

'Our classrooms are often very full. We also have no high school here [in Ritchie]. This means that our older children have to travel far to get secondary education.' (Participant 5, male, ward councillor) And then, because the last time I spoke to them, they were complaining that most children have finished their matric, but they're sitting there. They don't have bursaries or anything, and then, to them, they think this thing is going to ... it's not going to motivate those who are studying. How can our children go and study if we don't have money?' (Participant 7, male, school principal)

'Many people here don't have any training. This is why they do not

have jobs.' (Participant 5, male, ward councillor)
'In the past, we used to do this stuff for the tourists [arts and crafts], 'In the past, we used to do this stuff for the tourists [arts and crats
but we stopped because we are not getting help from the park [MNP].' (Participant 6, male, ward councillor)

'We get up early in the morning to go to the clinic. When we get there, there are already many people waiting. We sit there all day and by the end of the day, they tell you, you must come back.'

(Participant 15, female, community member)

'We have no capacity ... and we have many problems in Ritchie such as alcohol abuse, domestic violence, teenage pregnancy and so on.' (Participant 13, female, social worker)

'We have many challenges. Sometimes there is no water, and in some parts there is no electricity. The biggest needs are in the informal area [of Ritchie].' (Participant 5, male, ward councillor)

'Littering is a big problem. They [the municipality] only come once a week. It is not enough. People are getting sick.' (Participant 11, female, clinic nurse)

When asked about policing in the region, one participant simply stated: 'nothing happens.' (Participant 16 , female, community member

'There is nothing to do for our children. They just sit in the streets. This is not good because, sometimes, they are naughty.' (Participant 12 , female, social worker)

'Here [in Ritchie] our leaders only look after themselves and their families. We suffer. They do not help the people. They only help themselves.' (Participant 5, male, ward councillor) 


\section{Results}

\section{Phase 1: Identified community needs}

The framework developed by Sirgy et al. (2009) was used to cluster the 17 themes and subthemes that were identified via the thematic analysis of the semi-structured interviews (Phase 1) under the four categories: business services, government services and non-profit-related services, as well as community conditions. Table 2 summarises the main findings that emerged from the analysis and illustrates each with a relevant excerpt from the interviews.

\section{Phase 2: Empirical verification and quantification of community needs}

On the basis of the qualitative themes outlined in the previous section, a structured questionnaire was developed and subsequently administered during the second phase of the study. The survey results (see Table 3) confirmed that all the needs that were identified during the qualitative phase of the study are actual needs in the communities, whilst it also enabled the empirical quantification of the relative strength and prevalence of these needs.

According to the participants from both communities, the need for job opportunities was the most pressing (mean $=4.16$, $\mathrm{SD}=1.22$ ). This was confirmed by the fact that $53.3 \%$ of adult participants surveyed were unemployed (see Table 1). The second biggest need was for improved healthcare services (mean $=4.1, \mathrm{SD}=1.14$ ). This was followed by a number of government-related services such as the need for improved infrastructure (mean $=4.09 ; \mathrm{SD}=1.14)$, improved waste management $($ mean $=4.08 ; \mathrm{SD}=1.13)$, improved municipal service delivery $($ mean $=4.07 ; \mathrm{SD}=1.11$ ), improved safety and security (mean $=4.03$; $\mathrm{SD}=1.30$ ), improved community policing (mean $=4.00$; $\mathrm{SD}=1.24$ ), skills development and training (mean $=3.96 ; \mathrm{SD}=1.27)$ and improved social services ( mean $=3.96$; $\mathrm{SD}=1.11$ ).
Residents of both communities also felt that there was a significant need for an improvement in public education in their communities, both in terms of the quality and quantity of available educational institutions (mean $=3.95, \mathrm{SD}=1.09$ ).

The survey results also indicate that residents of Ritchie and Ratanang experienced the need for enhanced conservation of their local environments (mean $=3.91$, $\mathrm{SD}=1.2$ ). A marked need for recreational and sporting facilities is evident not only from the survey results (mean = $3.9, \mathrm{SD}=1.2$ ) but was particularly emphasised during the semi-structured interviews that were conducted with community members. Other needs such as improved local leadership, agricultural support and training and the need for local economic development also achieved an aboveaverage score.

\section{Phase 3: Extent to which Mokala National Park and South African National Parks can potentially address identified community development needs}

During the third phase of the study, semi-structured qualitative interviews as well as structured and unstructured questionnaires were used to gather data from purposively selected staff members from MNP and SANParks as well as other experts in relation to the extent to which parks such as MNP can potentially address the development needs that were identified by the communities. Whilst the sample was small, given the expertise of the participants and the need to identify the relative feasibility of each need being addressed, it was deemed to be of value to quantitatively assess all participants' views on the feasibility of each need being addressed (which was done on a five-point scale ranging from $1=$ 'not at all' to $5=$ 'to a great extent'). This rating was used as the basis for a qualitative exploration of why the participant assigned the given score. Participants' responses to the survey are reflected in Table 4 . Following on Table 4,

TABLE 3: Needs of total group and two communities.

\begin{tabular}{|c|c|c|c|c|c|c|}
\hline \multirow[t]{2}{*}{ Needs } & \multicolumn{2}{|c|}{ Total } & \multicolumn{2}{|c|}{ Ritchie } & \multicolumn{2}{|c|}{ Ratanang } \\
\hline & Mean & SD & Mean & SD & Mean & SD \\
\hline More job opportunities & 4.16 & 1.22 & 4.08 & 1.27 & 4.35 & 1.08 \\
\hline Improved healthcare services & 4.11 & 1.14 & 4.03 & 1.13 & 4.31 & 1.07 \\
\hline Improved infrastructure & 4.09 & 1.14 & 4.02 & 1.20 & 4.25 & 1.02 \\
\hline Improved waste management & 4.08 & 1.13 & 4.09 & 1.15 & 4.10 & 1.01 \\
\hline Improved municipal service delivery & 4.07 & 1.11 & 4.04 & 1.13 & 4.17 & 1.05 \\
\hline Improved community policing & 4.00 & 1.24 & 3.97 & 1.30 & 4.07 & 1.15 \\
\hline Skills development and training & 3.96 & 1.27 & 3.83 & 1.33 & 4.23 & 1.11 \\
\hline Improved social services & 3.96 & 1.11 & 3.98 & 1.12 & 3.96 & 1.08 \\
\hline Improved quality and quantity of education & 3.95 & 1.09 & 3.97 & 1.05 & 3.96 & 1.14 \\
\hline Improved local leadership & 3.94 & 1.16 & 3.97 & 1.17 & 3.93 & 1.12 \\
\hline Local conservation initiatives & 3.91 & 1.20 & 3.86 & 1.26 & 4.07 & 1.04 \\
\hline Recreation facilities and activities & 3.90 & 1.20 & 3.86 & 1.39 & 4.05 & 1.11 \\
\hline Agricultural support and training & 3.77 & 1.36 & 3.70 & 1.42 & 3.96 & 1.17 \\
\hline Local economic development & 3.74 & 1.15 & 3.70 & 1.10 & 3.86 & 1.21 \\
\hline More schools & 3.73 & 1.19 & 3.86 & 1.10 & 3.53 & 1.32 \\
\hline
\end{tabular}

Note: All needs were measured on a five-point scale that ranged from 1 ('no need') to 5 ('very large need').

SD, standard deviation. 
TABLE 4: Extent to which Mokala National Park and South African National Parks could potentially address development needs in communities.

\begin{tabular}{lc}
\hline Need & Mean \\
\hline More temporary job and employment opportunities & 4.00 \\
Local conservation initiatives & 3.83 \\
Skills development and training & 3.00 \\
Local economic development & 2.50 \\
Agricultural support and training & 2.33 \\
More permanent job and employment opportunities & 2.33 \\
Improved quality and quantity of education (primary and secondary) & 2.33 \\
Improved recreation facilities, activities and/or opportunities & 2.17 \\
Improved waste management & 2.00 \\
\hline Access to tertiary education (e.g. via bursaries, in-service learning) & 1.67 \\
Improved infrastructure & 1.50 \\
Improved local leadership & 1.50 \\
Improved municipal service delivery & 1.33 \\
Improved community safety and security & 1.17 \\
Improved community policing & 1.17 \\
\hline Establishing and building more schools & 1.17 \\
Improved availability of and/or access to healthcare services (e.g. clinics) & 1.00 \\
Improved social services & 1.00 \\
\hline
\end{tabular}

the needs - in order of their ranked importance and based on the themes derived from the qualitative data - will be discussed in greater detail.

\section{More temporary job and employment opportunities}

According to the participants, the biggest direct impact that MNP and SANParks can potentially have is via temporary job or employment opportunities (mean $=4.00)$. As sketched by one of the participants:

'Mokala currently employs nine contractors and each contractor employs 10 or 11 people. This means that nearly 100 contract workers are currently working on one of the Expanded Public Works Programme (EPWP)/Biodiversity Social Project (BSP) activities in the park, for example infrastructure projects, working for ecosystems, working for water, environmental monitors, et cetera.' (Participant 22, male, park manager)

According to the same participant, these temporary job opportunities are creating employment in all national parks in South Africa. The participant also commented that these projects have a lot of potential to address needs related to employment, because the projects' lifecycle typically extends over a period of 2 to 3 years and are often repeated, based on the availability of funding and the need for such services.

The participants also indicated that another opportunity for job creation in parks is to offer concessions to private investors, for example, by outsourcing a park's restaurants, shops, et cetera. According to one of the participants, some of the larger parks such as the Kruger National Park (KNP) are already engaging in this practice, resulting in an increase in the availability of jobs for people from local communities. However, as pointed out by the same participant, this is currently not a feasible strategy at MNP because the park is very remote, its restaurant is not showing much of a profit and accommodation for staff is limited.

\section{Local conservation initiatives}

According to expert participants, the second biggest potential impact that MNP and SANParks could have is in the local conservation space, especially via environmental education (EE). Not only is this in line with SANParks' primary mandate, but SANParks already has dedicated staff who can attend to this (its People and Conservation staff) and has a whole array of educational material on hand. As one participant pointed out, 'SANParks also has a fully developed curriculum for environmental education and it has specific programmes aimed at stimulating local conservation initiatives such as its Kids in Park programme' (Participant 23, female, People and Conservation officer). According to the same participant, part of MNP's efforts to stimulate local conservation initiatives includes taking children from local communities to visit the park for up to 2 to 3 days to learn and to be exposed to natural environments and wildlife. This programme, according to another participant (Participant 25, male, head of the park interface programme), has been rolled out at all the local schools in the area.

\section{Skills development and training}

The third biggest potential impact that MNP and SANParks can have is via skills development and training. This is largely because of the government-funded BSP/EPWP programmes. According to the participants, training is specifically budgeted for in each of these projects because it is mandatory to train community members temporarily employed through BSP/EPWP in a variety of fields like health, safety and first aid. Furthermore, given that many of these projects are often infrastructure related, for example, building staff accommodation at and erecting a new entrance gate for MNP's Lilydale Camp, participants have the opportunity to acquire practical skills pertaining to the construction industry, which they can subsequently apply in their own communities in support of development (e.g. building various structures).

According to the participants, contractor development also formed an important part of skills development (business management, health and safety, etc.) in the past, the idea being that SANParks should help to empower contractors so that they can secure other job opportunities (contracts) once their contracts with SANParks have expired.

\section{Local economic development}

According to one of the participants, MNP spends a portion of its budget in the local economies of Jacobsdal and Modderrivier, but the majority of its budget is spent in Kimberley: 'We do buy local as far as possible. However, some of the foods are not locally available. We therefore have to get it from Kimberley' (Participant 22, male, park manager). However, according to the same participant, Mokala, like all other parks, spends a large portion of its budget on human resources. According to him, at least some of the staff reside in local communities, implying that they also spend a portion of their income at local shops in towns near parks. As such, 
parks likely have a significant indirect impact on local economic development by means of the disposable income their employees spend in these communities.

Another potential option, according to the same participant, is to focus on supply-chain development. He explained that MNP currently purchases all the meat it uses in its restaurant from a local butcher near the park. Most of the dry food is, however, bought in Kimberley. According to him, much more can be done to identify, source and register local suppliers. In fact, MNP recently undertook an exercise to meet and register local service providers. A potential obstacle that was identified in this process is that suppliers have to be registered on a government database. However, this process is reported to be fairly rapid and inexpensive and, as such, need not pose an undue obstacle to local community members registering their businesses as suppliers. In this regard, national parks like MNP can and have played a supportive role by assisting new service providers with the registration process.

\section{Agricultural support and training}

According to the participants, MNP and some of the other national parks are in the process of providing agricultural support and training to local communities. This is currently happening in the Salt Lake community near Mokala. Other parks, such as the Karoo National Park, also focused on this in the past with the help of external service providers. In this regard, the participants felt that the People and Conservation officers can make a huge contribution and that basic skills can be transferred to local communities near parks, which, in turn, can contribute to food security in these communities.

Another participant also indicated that yet another way in which SANParks currently supports agriculture is through its wildlife economy programme, an initiative whereby SANParks gives animals to upcoming farmers on loan to build up their own breeding stock for commercial purposes. MNP is also taking part in this initiative.

\section{More permanent job and employment opportunities}

The participants indicated that MNP and SANParks' capacity to provide permanent job opportunities is limited (mean $=2.33$ ). This state of affairs was confirmed in the present study where only two individuals from the Ritchie community were reported to be employed by MNP and only one resident was employed by SANParks' regional office in Kimberley. This, according to the participants, can be ascribed to the fact that Mokala is still a developing park and small compared to other parks: 'There are some expectations, but Mokala is a small park compared to Kruger and can only contribute a small fraction' (Participant 23, female, People and Conservation officer).

According to another participant, the creation of job opportunities in parks will also depend on the staff turnover at the parks (via natural attrition, resignations and retirements).
This, according to him, is relatively low at present, thus limiting the capacity of parks like MNP to address this need in a feasible manner.

Another limiting factor that has an influence on the creation of job opportunities, according to the participants, is that some of the higher (more specialised) post levels require some formal education (graduate or postgraduate qualification), which ordinary community members from local communities often do not have.

One of the participants also indicated that in her experience, local community members are not aware of the employment opportunities that exist in parks. As a result, MNP is in the process of implementing the Yes Programme, which is a programme by the national government that is aimed at creating awareness among the youth of the type of job opportunities that exist in parks and within other government institutions.

\section{Improved quality and quantity of education}

The participants agreed that they, as a park and as part of SANParks, will not be able to improve the quality of education offered by local primary and secondary schools, nor the quantity of those schools in the area. They did, however, concede that SANParks can support the curriculum by providing context and practical exposure to school children, especially via their EE programmes and initiatives.

\section{Recreation facilities and activities}

According to one of the participants, SANParks can play a supporting role in the development of municipalities' Integrated Development Plans, especially when it comes to providing inputs regarding the development of urban parks and open spaces.

A second option, according to the participants, is for communities to make use of the free-entrance week that is normally offered by all national parks in South Africa in the course of September.

Yet another alternative mentioned by Participant 22 is to make use of the honorary ranger's project that, among others, involves hosting an annual mountain bike race in MNP. This initiative, according to him, has a lot of potential to involve developmental groups from the local community.

\section{Improved waste management}

Although MNP, and parks in general, cannot take the responsibility for waste management outside the park or in local communities, the participants indicated that improved waste management is a need that they share with local communities.

One of the participants also indicated that MNP is in the process of developing a recycling plant at the park. According to him, this can potentially provide opportunities 
for local communities. However, given that there are no waste depots or landfill sites near the park, all waste will have to be transported to the town of Kimberley over a distance of $90 \mathrm{~km}$, which is likely to affect the feasibility of this strategy adversely from a community development perspective.

\section{Access to tertiary education}

According to the participants, SANParks at present only offers bursaries to its own staff and their children, which implies that even though some of these employees do reside in local communities, the capacity to address this need is limited. However, SANParks also has a junior scientist programme that provides opportunities for upcoming scientists to obtain a master's degree or PhD. According to one of the participants, the programme started in KNP and will be expanded to other parks as well. In addition, SANParks is providing in-service training to graduates with a diploma or degree in conservation, and some of the beneficiaries have even been absorbed as section or field rangers or biotechnicians.

\section{Improved infrastructure}

The participants indicated that it would be difficult (if not impossible) for them as a park to address the larger infrastructural needs of their surrounding communities. However, according to them, SANParks does have a socioeconomic development department that assists with some of the infrastructure needs in communities (e.g. at schools and with regards to libraries). These interventions are funded by a percentage of the conservation fees that are paid by tourists.

\section{Improved leadership}

Here, too, the participants agreed that SANParks cannot really make a significant direct contribution. However, according to one of the participants, SANParks is making an indirect contribution through its Kids in Parks programme, because this programme is aimed at instilling leadership ethics at an early age, especially with regards to the disciplines of conservation and biodiversity.

\section{Improved municipal service delivery}

The participants indicated that they, as a park and SANParks in general, will not be able to address needs related to service delivery in local communities outside the park. The participants were fairly unanimous that this is the responsibility of local municipalities.

\section{Improved community safety, security and policing}

Participants felt that the need for improved safety and security and better policing in communities cannot be feasibly addressed by SANParks to any significant extent. Nevertheless, given that parks do indeed take measures to ensure security both inside the park and along their boundaries, it stands to reason that their immediate neighbours must be benefitting from these measures to some degree.

\section{Establishing more schools}

The participants unanimously felt that MNP and SANParks will not be able to make a significant contribution towards the actual building of more schools.

\section{Improved availability of and/or access to healthcare services (e.g. clinics)}

Participants indicated that the need for improved availability of and/or access to healthcare is a need they share with local communities. According to them, some of their staff members have to travel all the way to Kimberley to get treatment and/or chronic medication. Because the park is quite a distance from Kimberley, this involves hours of travel and adversely affects productivity. Negotiations with the department of health to build a clinic nearby or in the park are currently underway. Nevertheless, participants indicated that SANParks' direct potential contribution to addressing this need is minimal.

\section{Improved social services (e.g. social workers)}

All the participants agreed that addressing the need for improved social services falls completely outside their mandate and capacity.

\section{Discussion}

This study investigated the feasibility of national parks in South Africa endorsing a community development agenda, using MNP and two neighbouring communities as case study. A sequential mixed-methods approach was followed, comprising three phases that spanned a 3-year period.

In relation to the first two phases of the study, which aimed to investigate community needs both qualitatively and quantitatively, findings revealed that the communities' most significant needs centre around employment opportunities; improved healthcare, service delivery and waste management; an improvement in the quality of and access to primary and secondary education opportunities (i.e. schools); and more opportunities for local residents to afford and access tertiary education opportunities. Community members also expressed the need for improved community policing, safety and security; social services and agricultural support and training as well as general skills development and training, local leadership, recreational facilities, local economic development and conservation initiatives.

As will be outlined in the section to follow, the results from the third phase of the study suggest that MNP (and SANParks in general) could realistically only address some of the identified community needs to a significant degree.

The need for employment opportunities as well as the need for skills development and training ranked tops among those identified by the communities targeted in this study. Given that studies by Tepela and Omara-Ojungu (2012) in communities near KNP and by Pelser et al. (2013) near the 
Golden Gate Highlands National Park revealed similar results, it should come as no surprise that addressing the high unemployment rate in South Africa - identified as one of the 'five key pillars' of national government - has been adopted as a key element in SANParks' vision. In reaction to national government's call to address the unemployment rate, MNP/SANParks indicated that their biggest potential contribution would be in the form of temporary job creation, mainly via the EPWP/BSP programmes. In 2015-2016, three EPWP/BSPs were in operation at Mokala (Spies 2015). Since then, this number has increased to nine - which shows that there is still potential for growth.

Findings derived from the semi-structured interviews in this study confirmed that members of the Ritchie community did indeed benefit from the EPWP/BSP initiative and that over 100 local community members are currently benefitting from these programmes initiated by MNP, but the findings also revealed that several challenges are being experienced in as far as job allocation and the timely settlement of payments are concerned. From the park's perspective, Spies (2015) found the initiatives to be fairly successful, despite some challenges.

According to SANPark's 2015-2016 annual report, EPWP/ BSP programmes are on offer in all 19 South African national parks, and 23298 local community members are being employed on a semi-permanent basis (given that projects typically span 2 to 3 years and are often renewed).

These projects simultaneously also address the community need for skills development and training, as all temporary employees are being trained in a whole array of skills ranging from first aid to construction, some of which might increase their future employability and/or their ability to support local economic or infrastructure development in their own communities by, for example, making use of the skills they have acquired in the construction industry to erect structures in their own communities.

The creation of permanent jobs, though, seems to be a totally different matter that depends on the size of a particular park, its potential for expansion and the turnover of existing staff members. However, given that SANParks employs only around 4000 people countrywide (SANParks 2016) and that funds allocated to national parks are limited (SANParks 2016), the number of people that can be employed by the organisation on a permanent basis is clearly limited.

Two potential avenues for job creation that have probably hitherto been underutilised are to make private concessions available to private investors and to create more opportunities for self-employment. In case of the former, it is likely that private investors will have the capital to grow SANParks' facilities such as restaurants and accommodation and, in the process, to create more job opportunities.

Given that MNP and other parks are already engaging in the practice of sourcing supplies locally, another feasible strategy that could be investigated would be to establish and develop vetted local supply chains with communities adjoining national parks. Given that they are mostly rural (i.e. agricultural), residents could be afforded the opportunity to provide parks with an array of fresh vegetables, fruit and meat or an assortment of arts and crafts. Such a practice is also likely to make a meaningful contribution to local economic development.

The capacity to address the need for local conservation initiatives was ranked second highest. Given that environmental conservation is one of its core mandates, national parks can definitely play a significant role in this regard. Not only would such initiatives fall within SANParks' expertise, but the organisation also has the capacity to address these needs via its People and Conservation division (a programme by SANParks that is used to drive the dual agenda of conservation and development) and the various extension programmes it has on offer. Furthermore, SANParks can also play a role in the development of new conservation areas in traditional and cultural land via collaborative engagement with local communities.

A very pertinent need that was identified in the communities was for recreational facilities and activities. Whilst participants felt that direct involvement in the establishment of recreational facilities generally falls outside the scope of SANParks' mandate, the results of this study do suggest a couple of strategies that could be assessed for feasibility. These include sponsoring recreational facilities (e.g. participants in both communities expressed the need for a skateboard park), sponsoring local residents' participation in the annual park mountain bike race or promoting the park itself as recreational facility, perhaps via sponsoring occasional transport and entry into the park as is currently the case with the freeentrance week that usually occurs in September of each year. The latter strategy would represent a synergistic approach as it combines the park's core asset with a community need, which, as repeatedly revealed in the qualitative interviews, is likely to make a significant positive difference in the lives of residents of impoverished communities.

The findings suggest that MNP and other parks can play a significant role in agricultural support and training. In this regard, parks can partner with external service providers and provide wildlife to emerging farmers. Agricultural support and development is an international priority (linked to sustainable development goals) simply because it has a bearing on food security (FAO 2018). It also forms an integral part of South Africa's national development plan, given that it is part of government's efforts to stimulate integrated and inclusive rural economies in South Africa (The Conversation 2017).

A shared need that was identified by the communities and MNP was for improved waste management. Whilst direct involvement in refuse removal falls outside the auspices of SANParks' community development mandate and CBC 
initiatives, in this case, it could potentially play a role in terms of promoting environmental awareness and education. This would also be in the interest of national parks, given that refuse and pollution generated by local communities adjacent to national parks have the potential to impact the park and visitors' perceptions and experiences of the park adversely. In partnership with local authorities, the barriers that prevent people from keeping their communities clean can be identified and addressed. For example, MacAllister (2015) found that there were instances where managing farm waste as a health problem served as a means to help address this issue in communities and to prevent concomitant health issues.

Although MNP indicated that it cannot directly contribute to infrastructure development in local communities (e.g. roads, buildings, sanitation, etc.), it can play a role through its socio-economic development initiatives by supporting local supply-chain development and providing skills (such as construction skills) and opportunities to local community members. The beneficiaries of these initiatives can then, in turn, use the skills they have acquired to benefit their communities.

A huge need that was identified by the communities was to improve education. Whilst the findings clearly reveal that SANParks can only play a limited role in the context of formal education and cannot do much to increase the quantity and quality of schools in the region, it can nevertheless play a meaningful educational role by providing new learning opportunities and contexts for children. A number of parks already have some very good educational programmes and projects in place. Included among these are the heritage project Imbewu (developed to promote the transference of traditional cultural knowledge from older to younger people), the junior rangers programme (aimed at promoting civil service and volunteerism in parks), the Kids in Parks programme (aimed at exposing youngsters to parks and pristine natural environments) and the Koedoe Green Schools Programme (an EE programme focusing on, among others, climate change) (SANParks 2017). The potential value of projects such as these were underscored in the present study, where several participants reported that their children showed a marked change in their attitudes and enthusiasm towards the natural environment after a visit to MNP. Findings from the interviews revealed that whilst children would often kill animals such as snakes on sight, those who experienced a guided visit to MNP not only ceased this practice but actively encouraged others in the community to refrain from doing so.

Nevertheless, whilst valuable in itself, exposure to parks and EE will likely not promote the educational agenda necessary for people to matriculate with flying colours or to find gainful employment. This notion is supported by Van der Berg et al. (2011), who found that the level of education in rural communities bordering national parks is typically insufficient for learners to further their tertiary education at a university or college. Limited access to tertiary educational institutions (which was also found in the survey to be a significant community concern and need) and lack of funding, as well as lack of awareness of funding opportunities, conspire to exacerbate this problem. Even though both government and universities are currently doing a lot to assist communities in this regard (DHET 2017), national parks could also potentially play a significant role by, for example, offering bursaries to communities for those who wish to study science or conservation. In the long run, this will enhance the probability that residents originating from these communities may well end up finding permanent employment within a park structure.

Finally, the results indicate that there is very little that MNP and SANParks can feasibly do to directly address needs related to healthcare services (even though they share the need), community safety and security, community policing, social services (e.g. social workers), local leadership and the establishment and erection of more schools, as these needs generally fall outside the auspices and capacity of national parks in South Africa.

Elsewhere, Naughton-Treves, Buck Holland and Brando (2005) came to the same conclusion, whilst Andam et al. (2010) also questioned the actual impact national parks could have on poverty.

In light of the above, it seems necessary to rethink and possibly reconceptualise the developmental agenda that national parks are expected to drive so that these aims are more in line with (1) what parks can reasonably achieve based on resources, capacity and expertise and (2) what communities surrounding national parks need according to their own articulation. Failure to do so could invite the risk of creating unrealistic expectations among communities, resulting in an increased likelihood of general resentment and negative attitudes towards conservation among communities when such expectations are not fulfilled (Anthony 2007). Furthermore, though well-intentioned, community development initiatives that are not aligned with community needs or the capacity, resources and expertise of national parks are likely to either result in costly failures or might fail to truly have a meaningful impact on communities.

It is hoped that the findings of this study will be of use in informing SANParks' community development initiatives and ensuring that those initiatives are optimally aligned with actual community needs.

\section{Conclusion}

Using a sequential mixed-methods design, this study set out to investigate the feasibility of national parks in South Africa endorsing a community development agenda based on an exploration of community needs using MNP and two neighbouring rural communities as a case study. Based on the results, the feasibility of national parks substantively 
addressing all community needs is questioned as many of these needs fall outside the scope, capacity, skills and resource capability of the organisation.

Nevertheless, as was revealed in this study, national parks have the ability to directly or indirectly support several pressing community needs by creating jobs (especially by means of temporary projects and, to a far lesser extent, by means of direct employment) and by enabling those who partake in such employment opportunities to be trained and to develop specific skills. Furthermore, initiatives aimed at promoting awareness and education around waste management and local environmental conservation, supporting local economic development, sponsoring recreational facilities and/or access to parks as well as offering agricultural support and training have been identified as means whereby Mokala can respond to the needs experienced by its surrounding communities. Such initiatives would not only articulate with genuine community needs but could be feasibly pursued based on SANParks' expertise, resources and core mandate and thus hold the promise of truly achieving a positive impact on community development.

\section{Acknowledgements Competing interests}

The authors declare that they have no financial or personal relationship that may have inappropriately influenced them in writing this article.

\section{Authors' contributions}

Both authors contributed equally to conceptualising the study as well as towards collecting and analysing the data and writing the manuscript.

\section{Funding information}

This study was funded through a strategic research grant of the Unit of Environmental Sciences and Management, Faculty of Natural and Agricultural Sciences, North-West University.

\section{References}

Andam, K.S., Ferraro, P.J., Sims, K.R.E., Healy, A. \& Holland, M.B., 2010, 'Protected areas reduced poverty in Costa Rica and Thailand', Proceedings of the National Academy of Sciences 107(22), 9996-10001. https://doi.org/10.1073/pnas. 0914177107

Anthony, B., 2007, 'The dual nature of parks: Attitudes of neighbouring communities towards Kruger National Park, South Africa', Environmental Conservation 34(3), 236-245. https://doi.org/10.1017/S0376892907004018

Barrow, G.C., 2015, 'The socio-economic benefits of new national parks designations in Scotland', Association for the Protection of Rural Scotland 1, 2-13.

Bennet, N.J., 2014, 'Why local people do not support conservation: Community perceptions of marine protected area livelihood impacts, governance and management in Thailand', Marine Policy 44, 107-116. https://doi.org/10.1016/j. marpol.2013.08.017

Berkes, F., 2004, 'Rethinking community-based conservation', Conservation Biology 18(3), 621-630. https://doi.org/10.1111/j.1523-1739.2004.00077.x

Berkes, F., 2007, 'Community-based conservation in a globalized world', PNAS 104(39) viewed 10 January 2017, from http://www.pnas.org/content/104/39/15188.full.pdf

Biggs, D., Swemmer, L., Phillips, G., Stevens, J., Freitag, S. \& Grant, R., 2014, 'The development of a tourism research framework by South African National Parks to inform management', Koedoe 56(2), Art. \#1164, 9 pages.
Botha, J., Witkofski, E.T.F. \& Cock, J., 2007, "Is "something better than nothing"? The impacts of ten outreach nurseries on South African community stakeholders', Forests, Trees and Livelihoods 17, 199-221. https://doi.org/10.1080/14728028.2 Forests, Trees
007.9752597

Cock, J. \& Fig, D., 2000, 'From colonial to community based conservation Environmental justice and the national parks of South Africa. Society in Transition 31(1), 22-35. https://doi.org/10.1080/21528586.2000.10419008

Conley, A. \& Moote, M.A., 2003, 'Evaluating collaborative natural resource management', Society \& Natural Resources 16(5), 371-386. https://doi.org/ 10.1080/08941920309181

Cox, M., Arnold, G. \& Villamayor-Tomas, S., 2010, 'A review of design principles for community-based natural resource management', Ecology and Society 15(4), 38. https://doi.org/10.5751/ES-03704-150438

Creswell, J.W., 2003, Research design: Qualitative, quantitative, and mixed methods approaches, Sage, Thousand Oaks, CA.

Creswell, J.W., 2013, Qualitative inquiry and research design choosing among five approaches, Sage, Thousand Oaks, CA.

Creswell, J.W. \& Plano Clark, V.L., 2007, Designing and conducting mixed methods research, Sage, Thousand Oaks, CA.

Department of Higher Education and Training, 2017, Official website, viewed 10 January 2017, from http://www.dhet.gov.za/

Emerton, L., 2001, 'The nature of benefits and the benefits of nature: Why wildlife conservation has not economically benefited communities in Africa', in D. Hulme \& M. Murphree (eds.), African wildlife and livelihoods: The promise and performance of Community Conservation, pp. 208-226, David Philip Publ, Cape Town, South Africa.

Faasen, H., 2006, 'Synergies between biodiversity conservation and sustainable rural development of adjacent communities: A case study of the Tsitsikamma National Park', PhD thesis, University of Stellenbosch, Faculty of Agriculture and Forestry Sciences.

Field, A., 2005, Discovering statistics using SPSS, Sage, London.

Flora, C.B., Flora, J.L. \& Gasteyer, S.P., 2015, Rural communities: Legacy and changes, Westview Press, Boulder, CO.

Food and Agriculture Organization of the United Nations, 2018, viewed 10 August 2018, from http://www.fao.org/sustainable-development-goals/en/

IUCN, 2010, Policy matters 17, viewed 10 January 2017, from https://www.iucn.org/ downloads/policy_matters_17__pg_173_204.pdf

Johnson, R.B., Onwuegbuze, A.J. \& Turner, L.A., 2007, 'Toward a definition of mixed methods research', Journal of Mixed Methods Research 1(2), 112-133. https:// doi.org/10.1177/1558689806298224

Kusters, K., Achdiawan, R., Belcher, B. \& Perez, M., 2006, 'Balancing development and conservation? An assessment of livelihood and environmental outcomes of nontimber forest product trade in Asia, Africa, and Latin America', Ecology and Society 11(2), 20. https://doi.org/10.5751/ES-01796-110220

Lundmark, J.L., Fredman, P. \& Sandell, K., 2010, 'National parks and protected areas and the role for employment in tourism and forest sectors: A Swedish case', Ecology and Society 15(1), 19. https://doi.org/10.5751/ES-03175-150119

MacAllister, J., 2015, Factors influencing solid-waste management in the developing World, All Graduate Plan B and other reports. Paper 528, Utah State University, DigitalCommons@USU, Utah.

Machlis, G.E. \& Field, D.R., 2000, National parks and rural development: Practice and policy in the United States, Island Press, Washington, DC.

Mansuri, G. \& Rao, V., 2004, 'Community-based and -driven development: A critical review', World Bank Research Observer 19(1), 1-39. https://doi.org/10.1093/ wbro/lkh012

Mohan, G.,2009 'The significance of rural areas in South Africa for tourism development through community participation with special reference to Umgababa, a rural area located in the province of KwaZulu-Natal', University of South Africa, Pretoria, viewed 16 January 2017, from http://hdl.handle.net/10500/2159

Murphee, M.W. \& Hulme, D., 2001, African wildlife and livelihoods: The promise and performance of community conservation, James Currey Ltd, Oxford.

Naughton-Treves, L., Holland, M. \& Brando, K., 2005, 'The role of protected areas in conserving biodiversity and sustaining local livelihoods', Annual Review of Environment and Resources 30, 219-252. https://doi.org/10.1146/annurev.energy. 30.050504.164507

Nelson, J.G. \& Serafin, R., 2013, National parks and protected areas: Keystones to conservation and sustainable development, NATO ASI book series 40, SpringerVerlag, Berlin Heidelberg.

Newmark, W.D. \& Hough, J.L., 2000, 'Conserving wildlife in Africa: Integrated conservation and development projects and beyond', BioScience 50(7), 585-592. https://doi.org/10.1641/0006-3568(2000)050[0585:CWIAIC]2.0.CO;2

Pelser, A., Redelinghuis, N. \& Velelo, N., 2013, Protected areas as vehicles in population development: Lessons from rural South Africa, viewed 10 January 2017, from http://conferences.ufs.ac.za/dl/Userfiles/Documents/00001/654_eng.pdf

Petursson, J.G. \& Vedeld, P., 2017, 'Rhetoric and reality in protected area governance: Institutional change under different conservation discourses in Mount Elgon National Park, Uganda', Ecological Economics 131, 166-177. https://doi.org/10.1016/ j.ecolecon.2016.08.028

Pullin, A.S, 2014, Assessing the effects of terrestrial protected areas on human wellbeing: ASTAP Advisory Document, Global Environmental Facility, Washington, DC. 
Rights and Resource Initiative, 2015, Protected areas and the land rights of indigenous peoples and local communities: Current issues and future agenda, viewed 10 January 2017, from file:///C:/Users/12894451/Desktop/RRIReport ProtectedAreasand-LandRights_web.pdf

SANParks, 2012, SANParks Annual Performance Plan, viewed 10 January 2017, from https://www.sanparks.org/assets/docs/about/annual_performance_plan_ 2012013.pdf

SANParks, 2016, SANParks Annual Report 2015/16, viewed 10 January 2017, from https://www.sanparks.org/assets/docs/general/annual-report-2016.pdf

SANParks, 2017, Official website of South African National Parks, viewed 10 January 2017, from https://www.sanparks.org/about/connecting_to_society/

Sirgy, M.J., Widgery, R.N., Lee, D. \& Yu, G.B., 2009, 'Developing a measure of community well-being based on perceptions of impact in various life domains', Social Indicators Research 96, 295-311. https://doi.org/10.1007/s11205-009-9479-9

Spies, M.O., 2015, 'An exploration of whether the People and Parks Programme contributes to capacity building and awareness in the Ritchie community near Mokala National Park', Unpublished honours dissertation, North-West University, Potchefstroom Campus.

Stats-SA, 2011, Official website of Statistics South Africa, viewed 10 January 2017, from http://www.statssa.gov.za/?page_id=3839

Stevens, S., 2014, Indigenous peoples, national parks, and protected areas: A new paradigm linking conservation, culture, and rights, University of Arizona Press, Tucson, AZ.

Stolton, S. \& Dunley, N., 2015, Values and benefits of protected areas, ANU Press, Canberra, Australia.
Swemmer, L.K. \& Taljaard, S., 2011, 'SANParks, people and adaptive management: Understanding a diverse field of practice during changing times', Koedoe 53(2), 1-7. https://doi.org/10.4102/koedoe.v53i2.1017

Tashakkori, A. \& Teddlie, C., 2003, Handbook of mixed methods in social and behavioral research, Sage, Thousand Oaks, CA.

Tepela, B.N. \& Omara-Ojungu, P.H., 2012, 'Towards bridging the gap between wildlife conservation and rural development in post-apartheid South Africa: The case of the Makuleke community and the Kruger National Park', South African Geography Journal 81(3), 1999.

The Conversation, 2017, How land reform and rural development can help reduce poverty in South Africa, viewed 10 August 2018, from http://theconversation.com/howlandreform-and-rural-development-can-help-reduce-poverty-in-south-africa84146

Tisdell, C., 1999, Biodiversity, conservation and sustainable development: Principles and practices with Asian examples, Cheltenham, Edward Elgar.

Tracy, S.J., 2013, Qualitative research methods: Reflecting evidence, crafting analysis, communicating impact, Wiley-Blackwell, London.

Van der Berg, S., Taylor, S., Gustafsson, M., Spaull, N. \& Armstrong, P., 2011, Improving education quality in South Africa, Report for the National Planning Commission, Department of Economics, University of Stellenbosch.

Vira, B. \& Kontoleon, A., 2010, 'Dependence of the poor on biodiversity: Which poor, what biodiversity?', CPRC International Conference 2010, Manchester, September 8-10, 2010.

Wells, M.P. \& McShane, T.O., 2004, 'Integrating protected area management with local needs and aspirations', Ambio 33, 513-519. https://doi.org/10.1579/00447447-33.8.513

Western, D., Wright, R.M. \& Strum, S.C., 2013, Perspectives in community based conservation, Island Press, Washington, DC. 